Prepared in cooperation with the New York State Department of Transportation

\title{
Maximum Known Stages and Discharges of New York Streams and their Annual Exceedance Probabilities through September 2011
}

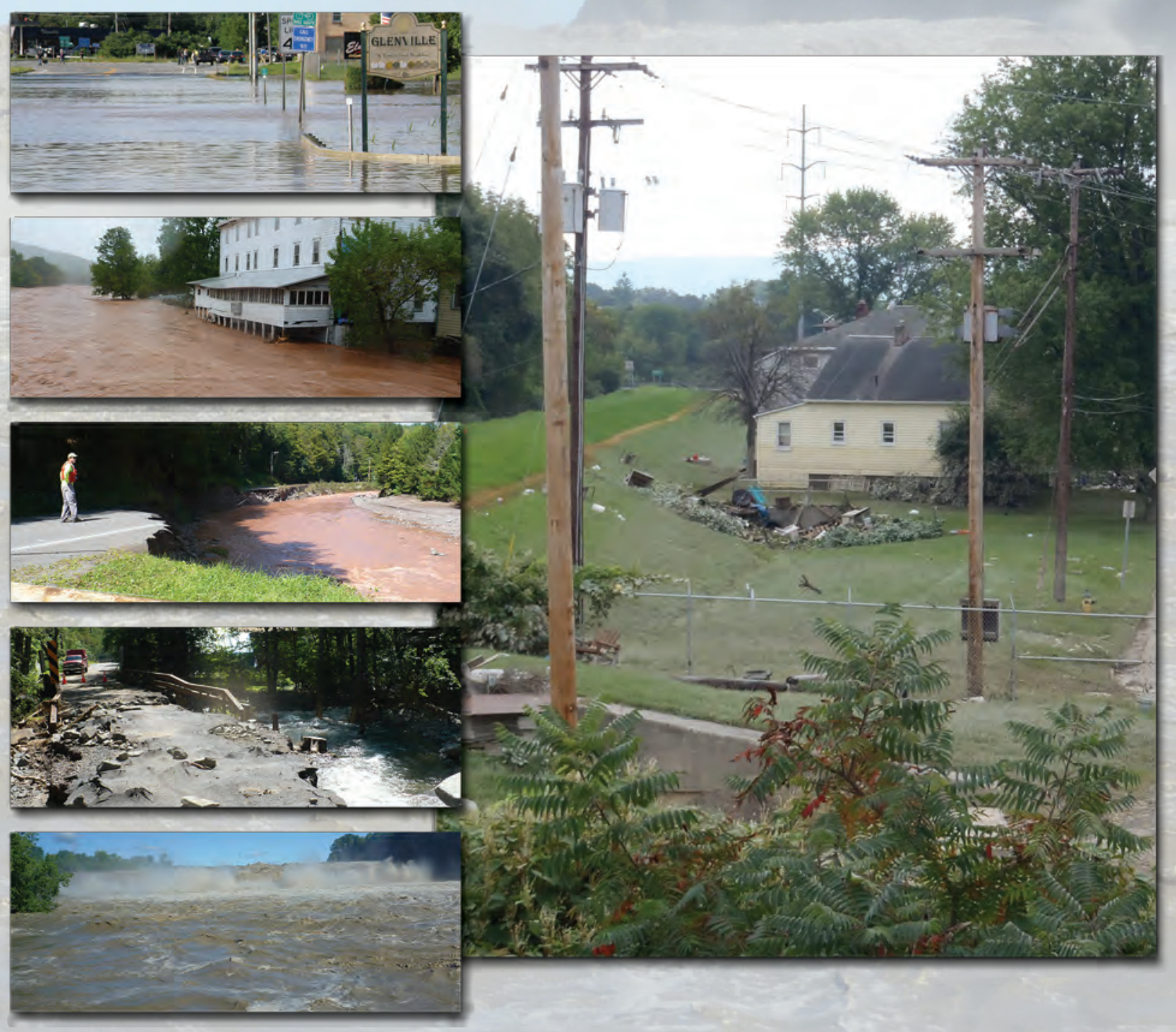

Scientific Investigations Report 2014-5084 


\begin{tabular}{|c|}
\hline$A$ \\
\hline$B$ \\
\hline \hline$C$ \\
\hline$D$ \\
\hline$E$ \\
\hline
\end{tabular}

Cover. Effects of August and September 2011 flooding in New York State along the $A$, Mohawk River in Glenville, $B$, Schoharie Creek in Lexington, $C$, East Kill near Jewett, D, Hollow Tree Brook near Lanesville, E, Mohawk River at Cohoes Falls, and $F$, Susquehanna River in Westover. 


\section{Maximum Known Stages and Discharges of New York Streams and their Annual Exceedance Probabilities through September 2011}

By Gary R. Wall, Patricia M. Murray, Richard Lumia, and Thomas P. Suro

Prepared in cooperation with the New York State Department of Transportation 


\title{
U.S. Department of the Interior SALLY JEWELL, Secretary
}

\section{U.S. Geological Survey Suzette M. Kimball, Acting Director}

\author{
U.S. Geological Survey, Reston, Virginia: 2014
}

For more information on the USGS - the Federal source for science about the Earth, its natural and living resources, natural hazards, and the environment, visit http://www.usgs.gov or call 1-888-ASK-USGS.

For an overview of USGS information products, including maps, imagery, and publications, visit http://www.usgs.gov/pubprod

To order this and other USGS information products, visit http://store.usgs.gov

Any use of trade, firm, or product names is for descriptive purposes only and does not imply endorsement by the U.S. Government.

Although this information product, for the most part, is in the public domain, it also may contain copyrighted materials as noted in the text. Permission to reproduce copyrighted items must be secured from the copyright owner.

Suggested citation:

Wall, G.R., Murray, P.M., Lumia, Richard, and Suro, T.P., 2014, Maximum known stages and discharges of New York streams and their annual exceedance probabilities through September 2011: U.S. Geological Survey Scientific Investigations Report 2014-5084, 16 p., http://dx.doi.org/10.3133/sir20145084.

ISSN 2328-0328 (online) 


\section{Acknowledgments}

The New York State Department of Transportation, the New York State Department of Environmental Conservation, the U.S. Army Corps of Engineers, the Hudson River-Black River Regulating District, the New York Power Authority, Reliant Energy, the New York City Department of Environmental Protection, and several other municipal and county governments provided support for data-collection programs.

The authors also wish to acknowledge the many talented and dedicated U.S. Geological Survey (USGS) personnel who contributed to data collection and analyses for this report, as well as Mark Roland and Scott Olson of the USGS, who provided valuable technical reviews of this report. 



\section{Contents}

Abstract
Introduction.
Data Compilation and Computation
$\quad$ Sources of Data.
$\quad$ Fategories of Data
$\quad$ Ted Frequency
$\quad$ Spatial Distribution of Maximum Known Discharges and Runoffs
Summary.
References Cited
Glossary

\section{Figures}

1. Map showing locations of 1,400 sites in the State of New York with peak discharge

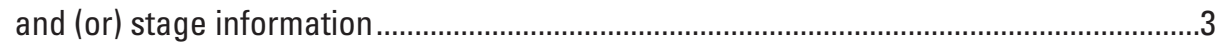

2. Map showing locations and geographic features noted in text.........................................4

3. Graphs showing timing of known peak discharges in the State of New York: $A$, number; $B$, percentage of streamgages with peak-of-record discharge less than or equal to the 1-percent annual exceedance probability (AEP), relative to the number of streamgages in operation; and $C$, peak discharges less than or equal to the 1-percent AEP discharge determined at miscellaneous-measurement sites...................6

4. Graphs showing maximum known discharges, known 1-percent annual exceedance probability (AEP) discharges for Rural10 sites, and the State of New York discharge envelope curve for A, State of New York; B-G, six hydrologic regions in New York; and $\mathrm{H}$, Long Island

5. Graphs showing maximum known runoff, known 1-percent annual exceedance probability (AEP) runoff for Rural 10 sites, and the State of New York runoff envelope curve for A, State of New York; B-G, six hydrologic regions in New York; and $\mathrm{H}$, Long Island.

6. Graphs showing envelope curves for A, discharge and B, runoff for the United States (Crippen and Bue, 1977), State of New York, six hydrologic regions in New York, and Long Island.

7. Boxplot showing distribution of maximum known $A$, discharge and $B$, runoff from 1,362 locations across six hydrologic regions in New York and Long Island (Region LI)

\section{Table}

1. Maximum known stages and discharges of New York streams through September 30, 2011, and annual exceedance probabilities for those streams with sufficient data for analysis (http//pubs.usgs.gov/sir/2014/5084)... 


\section{Conversion Factors and Datums}

\begin{tabular}{lcl}
\hline Multiply & By & \multicolumn{1}{c}{ To obtain } \\
\hline inch (in.) & Length & \\
inch (in.) & 2.54 & centimeter $(\mathrm{cm})$ \\
foot (ft) & 25.4 & millimeter $(\mathrm{mm})$ \\
mile (mi) & 0.3048 & meter $(\mathrm{m})$ \\
\hline Area & 1.609 & kilometer $(\mathrm{km})$ \\
\hline square mile $\left(\mathrm{mi}^{2}\right)$ & & \\
square mile $\left(\mathrm{mi}^{2}\right)$ & 259.0 & hectare $($ ha) \\
\hline & 2.590 & square kilometer $\left(\mathrm{km}^{2}\right)$ \\
\hline cubic foot per second $\left(\mathrm{ft}^{3} / \mathrm{s}\right)$ & Flow rate & \\
cubic foot per second per square & 0.02832 & cubic meter per second $\left(\mathrm{m}^{3} / \mathrm{s}\right)$ \\
mile $\left[\left(\mathrm{ft}^{3} / \mathrm{s}\right) / \mathrm{mi}^{2}\right]$ & 0.01093 & cubic meter per second $\mathrm{per}$ \\
cubic foot per day $\left(\mathrm{ft}^{3} / \mathrm{d}\right)$ & & square $\mathrm{kilometer}\left[\left(\mathrm{m}^{3} / \mathrm{s}\right) / \mathrm{km}^{2}\right]$ \\
& 0.02832 & cubic meter per day $\left(\mathrm{m}^{3} / \mathrm{d}\right)$ \\
\hline ton per day (ton $/ \mathrm{d})$ & Mass & \\
ton per day (ton/d) & 0.9072 & metric ton per day \\
\hline
\end{tabular}




\title{
Maximum Known Stages and Discharges of New York Streams and their Annual Exceedance Probabilities through September 2011
}

\author{
By Gary R. Wall, Patricia M. Murray, Richard Lumia, and Thomas P. Suro
}

\section{Abstract}

Maximum known stages and discharges at 1,400 sites on 796 streams within New York are tabulated. Stage data are reported in feet. Discharges are reported as cubic feet per second and in cubic feet per second per square mile. Drainage areas range from 0.03 to 298,800 square miles; excluding the three sites with larger drainage areas on the St. Lawrence and Niagara Rivers, which drain the Great Lakes, the maximum drainage area is 8,288 square miles (Hudson River at Albany). Most data were obtained from U.S. Geological Survey (USGS) compilations and records, but some were provided by State, local, and other Federal agencies and by private organizations.

The stage and discharge information is grouped by major drainage basins and U.S. Geological Survey site number, in downstream order. Site locations and their associated drainage area, period(s) of record, stage and discharge data, and flood-frequency statistics are compiled in a Microsoft Excel spreadsheet. Flood frequencies were derived for 1,238 sites by using methods described in Bulletin 17B (Interagency Advisory Committee on Water Data, 1982), Ries and Crouse (2002), and Lumia and others (2006).

Curves that "envelope" maximum discharges within their range of drainage areas were developed for each of six floodfrequency hydrologic regions and for sites on Long Island, as well as for the State of New York; the New York curve was compared with a curve derived from a plot of maximum known discharges throughout the United States. Discharges represented by the national curve range from at least 2.7 to 4.9 times greater than those represented by the New York curve for drainage areas of 1.0 and 1,000 square miles.

The relative magnitudes of discharge and runoff in the six hydrologic regions of New York and Long Island suggest the largest known discharges per square mile are in the southern part of western New York and the Catskill Mountain area, and the smallest are on Long Island.

\section{Introduction}

Information on the stages and discharges of streams during or following flooding is useful to designers of bridges, culverts, and dams and to floodplain managers. For over a century, the U.S. Geological Survey (USGS) has been collecting and documenting peak-stage and discharge data at continuous-record streamgages, partial-record streamgages, and at miscellaneous-measurement sites (see glossary) during and (or) after floods. Data are accessible through the USGS Peak Streamflow for the Nation website (http://nwis. waterdata.usgs.gov/usa/nwis/peak) and in USGS annual data reports that list peak stage and discharge data (Wells, 1960; U.S. Geological Survey, 1961-2011). Several USGS reports have documented maximum stages and discharges of New York streams (U.S. Geological Survey, 1960; Hendricks, 1964; Dunn, 1970; Leonard and Dunn, 1976; Robideau and others, 1984; and Lumia and Murray, 1993). The data presented in this report by the USGS, in cooperation with the New York State Department of Transportation, supersede those given in earlier reports.

This report is a compilation of all known maximum stages and discharges of New York streams on record at the USGS and includes some data furnished by State and local agencies and other Federal and private organizations. Data from 1,400 sites on 796 streams were compiled. The report (1) lists the sources and categories of data, (2) presents the maximum stage and discharge of each site in downstream order by river basin, (3) presents flood-frequency statistics for discharges on 1,238 of the sites, and (4) presents an analysis of the relation between discharge and drainage area for the State of New York and the timing of maximum discharge events recorded in New York since 1900. The report also includes a glossary of technical terms used in the text and table. 


\section{Data Compilation and Computation}

Several sources of data and categories of peak-stage and discharge data were researched and documented. In addition, flood frequency analyses were performed on 1,238 sites; a description of the methodologies employed in these analyses follows a description of the data compilation.

\section{Sources of Data}

Most of the peak-stage and discharge data in this report were obtained through the USGS National Water Information System (NWIS) database (accessed at http://nwis.waterdata. usgs.gov/usa/nwis/peak) and from miscellaneous-measurement files in the USGS offices in Troy, Ithaca, and Coram, N.Y. Most miscellaneous-discharge measurements were made by indirect methods (slope-area, contracted-opening, flow-overdam, or flow-through-culvert; see glossary for definitions). Information from previous USGS publications was used to supplement the peak-stage, discharge, and miscellaneousmeasurement site data. Other sources of peak-stage and discharge information were local organizations and Federal or State agencies such as the U.S. Army Corps of Engineers, the National Weather Service, and the New York State Department of Transportation.

\section{Categories of Data}

The categories of data included in this report are grouped according to the type of peak stage and (or) discharge measurement site: (1) continuous-record streamgage, (2) partial-record streamgage, and (3) miscellaneousmeasurement site. A definition of each category is given in the glossary. Continuous-record and partial-record streamgages are sites established by the USGS for specific hydrologic and (or) hydraulic studies, and their data are published in the resulting interpretive or data reports. Miscellaneousmeasurement sites are mostly sites where the USGS has made a peak-discharge measurement by indirect method. The miscellaneous-site category also includes stream sites at which State, local, and other Federal agencies and private organizations have determined peak stage or discharge and published the values. Locations of 1,400 sites at which peak discharge and (or) stage were recorded are shown in figure 1, along with areas of the State representing hydrologic regions of New York defined by Lumia and others (2006). The peak discharges at continuous- and partial-record sites represent periods of record ranging from 1 to over 100 years. A miscellaneous-measurement site peak represents the maximum peak at the site over an unknown period of time. Figure 2 shows site locations and geographic features discussed in this report.

\section{Flood Frequency}

Frequency analysis of annual flood-peak data recorded at streamgages provides a means of estimating the probability of occurrence of a given discharge. Flood frequency is commonly expressed in terms of a recurrence interval or the probability of being exceeded (one is the reciprocal of the other). The 100 -year flood, for example, has an annual exceedance probability (AEP) of 0.01 , equating to a 1 -percent chance of being equaled or exceeded in any given year.

AEP discharges for streamgages listed in table 1 (available for download as a Microsoft Excel spreadsheet by clicking the blue "table 1" text) were computed by: (1) a log-Pearson type III analysis, (2) regional flood-frequency equations, (3) a log-Pearson type III analysis weighted by results derived from regional flood-frequency equations, or (4) adjustments to the frequency statistics of a nearby site based on methods described in Ries and Crouse (2002) or Lumia and others (2006). For streamgages with at least 10 years of record (503 sites), AEP discharges were computed on the basis of annual peak streamflow data fit to a logPearson type III distribution by following methods described in Bulletin 17B of the Interagency Advisory Committee on Water Data (1982). Of those 503 sites, 359 were considered rural and unregulated on the basis of criteria in Lumia and others (2006) - for these sites (identified as "Rural10" in table 1) - generalized skew was determined from Lumia and Baevsky (2000) and used for the log-Pearson type III computations. Regional flood frequency equation results were then used to weight the log-Pearson type III results according to methods described in Lumia and others (2006). A dropdown menu in table 1 (activated by selecting cell F3) can be used to view the results of the log-Pearson type III, regional regression equation, and weighted log-Pearson analyses for these sites.

Flood frequency statistics at streamgages with at least 10 years of record and substantial regulation or urbanization were calculated from statistical analyses of annual peak discharges during the regulated period only, except for three sites along the main stem of the Delaware River at Callicoon, N.Y. (USGS Site ID 01427405); above the Lackawaxen River near Barryville, N.Y. (01428500); and at Port Jervis, N.Y. (01434000); these frequency statistics were calculated as part of a multiagency workgroup (Schopp and Firda, 2008) and have not been updated. These sites, indicated as "Urban" or "Regulated" in table 1, are not weighted with results from regional flood-frequency equations because these equations are only appropriate in rural settings. Flood frequency statistics at 15 sites (indicated as "Regulated*" or Urban*") with substantial regulation or urbanization, without at least 10 years of record, but located along the same stream as an "Urban" or "Regulated" site were calculated on the basis of equation 5 in Lumia and others (2006) when the drainage area at the Regulated* or Urban* site was within 50 to 150 percent of that of the gaged site. 


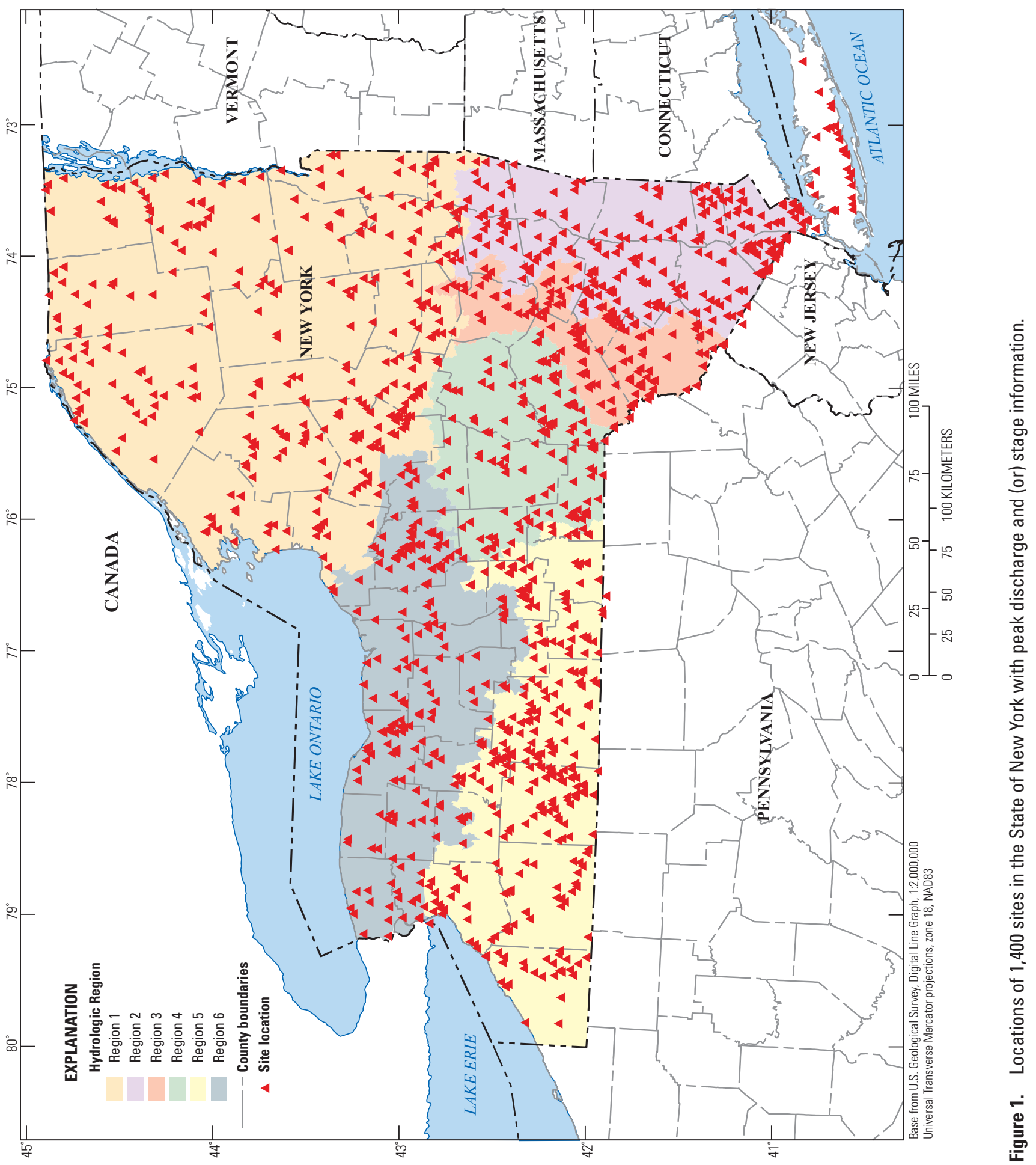




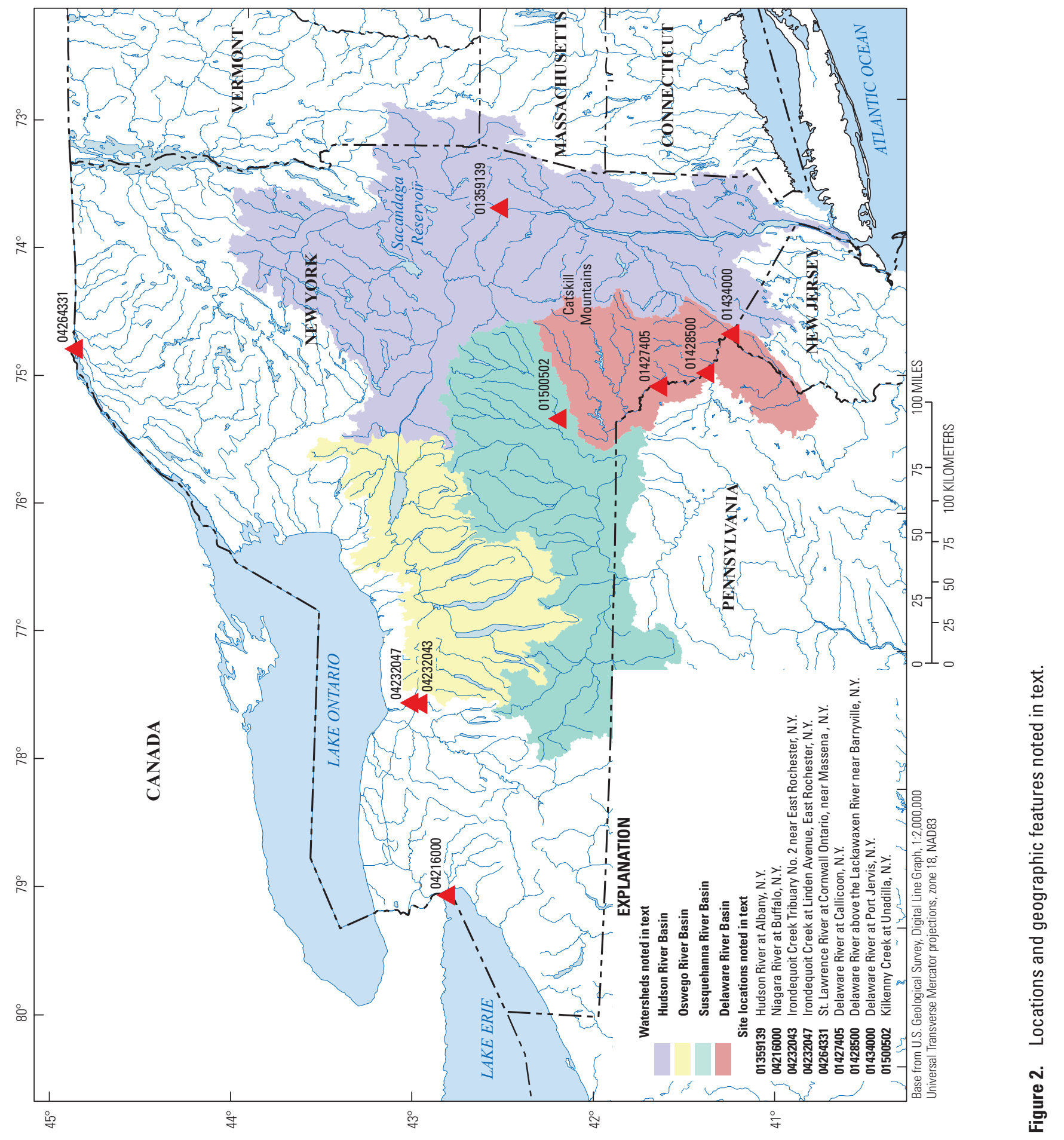


For rural sites in table 1 with less than 10 years of record (666 sites identified as "Rural" in table 1) the flood-frequency statistics are based solely on the regional flood-frequency equations. Caution should be exercised in the use of these AEP values because watershed conditions, such as the amount of impervious land cover, may have changed since the time of the peak discharge event. Watershed characteristics used in the regional equations were derived from the StreamStats for New York online tool (http://water.usgs.gov/osw/streamstats/new york.html, accessed June 5, 2013). Flood frequency statistics at 59 sites (indicated as "Rural10*") meeting the rural criteria, without at least 10 years of record, but located along the same stream as a "Rural10" site were calculated on the basis of methods in Ries and Crouse (2002) when the drainage area at the Rural10* site was within 50 to 150 percent of that of the gaged site.

No adjustments were made for the amount of available storage in reservoirs before or during floods or for changes in regulation procedures during the period of regulation. These flood frequency statistics supersede previously published statistics.

\section{Evaluation of Maximum Known Discharges}

In the State of New York, the maximum known discharge of 378,000 cubic feet per second $\left(\mathrm{ft}^{3} / \mathrm{s}\right.$ ) (a daily average) occurred on the St. Lawrence River at Cornwall, Ontario, near Massena, N.Y, (04264331), on three occasions, May 20, 1993; May 28, 1993; and June 8, 1993. The streamflow associated with this streamgage is highly regulated, and the basin drains water from an area 5.5 times greater than the entire State of New York; therefore, conditions here and at the Niagara River at Buffalo, N.Y. (04216000) (4.8 times the size of New York), are not typical of New York rivers and watersheds. The maximum known discharge, other than those recorded on the Niagara and St. Lawrence Rivers, was $240,000 \mathrm{ft}^{3} / \mathrm{s}$ on the Hudson River at Albany (01359139) on March 28, 1913.

The maximum recorded runoff (discharge divided by watershed area) event in New York State of 10,326 cubic feet per second per square mile $\left(\mathrm{ft}^{3} / \mathrm{s} / \mathrm{mi}^{2}\right)$ was the result of a break in the Erie Canal on October 29, 1974, which drained into a tributary of Irondequoit Creek Tribuary No. 2 near East Rochester (04232043); this site and the runoff computed in the receiving river (04232047) were not used to evaluate statewide maximum runoff. The maximum known runoff resulting from "natural" circumstances was estimated at 4,600 ft $\mathrm{ft}^{3} / \mathrm{s} / \mathrm{mi}^{2}$ on July 29, 1961, on the $0.5 \mathrm{mi}^{2}$ basin of Kilkenny Creek at Unadilla, N.Y. (01500502), following approximately 6 inches of rain over 4 hours (Robison, 1961).

\section{Temporal Distribution of Peak Discharges}

The temporal distribution of known peak discharges less than or equal to the 1-percent AEP discharge is illustrated in figure 3. Because the number of recorded peaks at streamgages is in part a function of the number of continuousand partial-record sites in operation at the time of a peak, period-of-record (see glossary) peaks from sites are shown numerically (fig. 3A) and normalized (fig. 3B) by the number of streamgages in operation for a given water year. Flooding associated with Tropical Storms Irene and Lee in 2011 and Hurricane Agnes in 1972 ranked 1 and 2 for the most peaks recorded in a particular water year (fig. 3A). Agnes flooding ranks sixth ( 8.3 percent) however, when normalized by the number of active gages at the time. The year 1902 ranks second, with 14.3 percent of the streamgages at the time experiencing a period-of-record peak less than or equal to the 1-percent AEP; however, this number is tempered somewhat by the fact that one of the three sites had a period of record of only 1 year. Third (10.8 percent) was March 1936 when heavy rain from four successive storms, and a melting snow pack, caused flooding in the Susquehanna, Delaware, and Hudson River watersheds (Grover, 1937). Fourth (9.6 percent) was July 1935 when thunderstorms dumped over 9 inches of rain across the headwaters of the Susquehanna and Oswego River watersheds in central New York (Johnson, 1936). Fifth (9.4 percent) was March 1913 when 4 days of heavy rains brought flooding to much of north-central New York and the Hudson River watershed (Gravlee and others, 1991). Hudson River flooding in 1913 generally is considered the final impetus for construction of the Sacandaga Reservoir as a Hudson River flood control measure.

Figure $3 \mathrm{C}$ depicts the temporal distribution of peak discharges less than or equal to the 1-percent AEP discharge at miscellaneous-measurement sites across New York. Although the high number of peaks in 1935 and 1972 is consistent with high numbers seen at streamgages across the State, it should be kept in mind that the number of peaks depicted in figure $3 \mathrm{C}$ is highly biased by the call (or lack of call) for flood documentation beyond the streamgage network. 


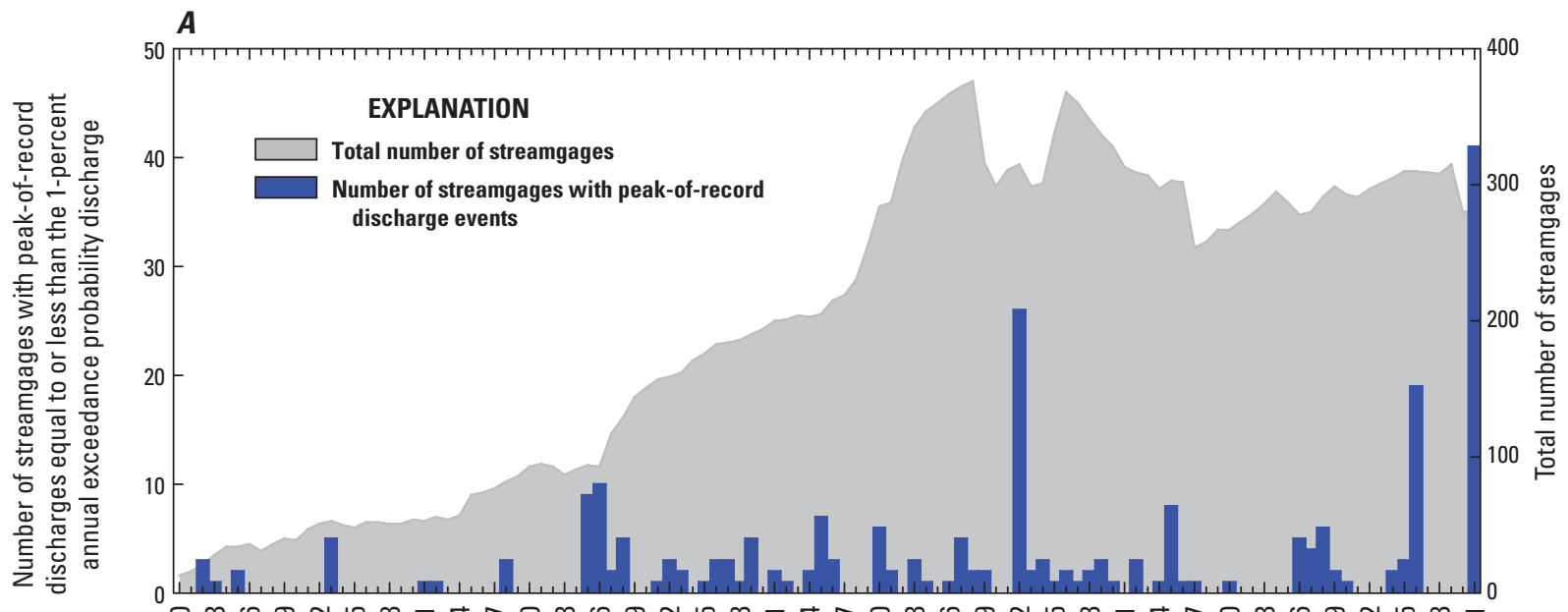

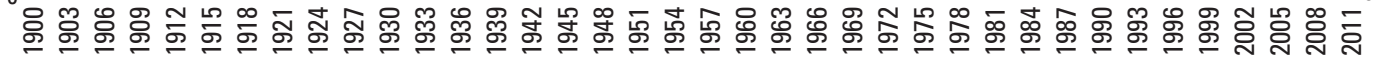

Water year (0ct. 1 to Sept. 30)

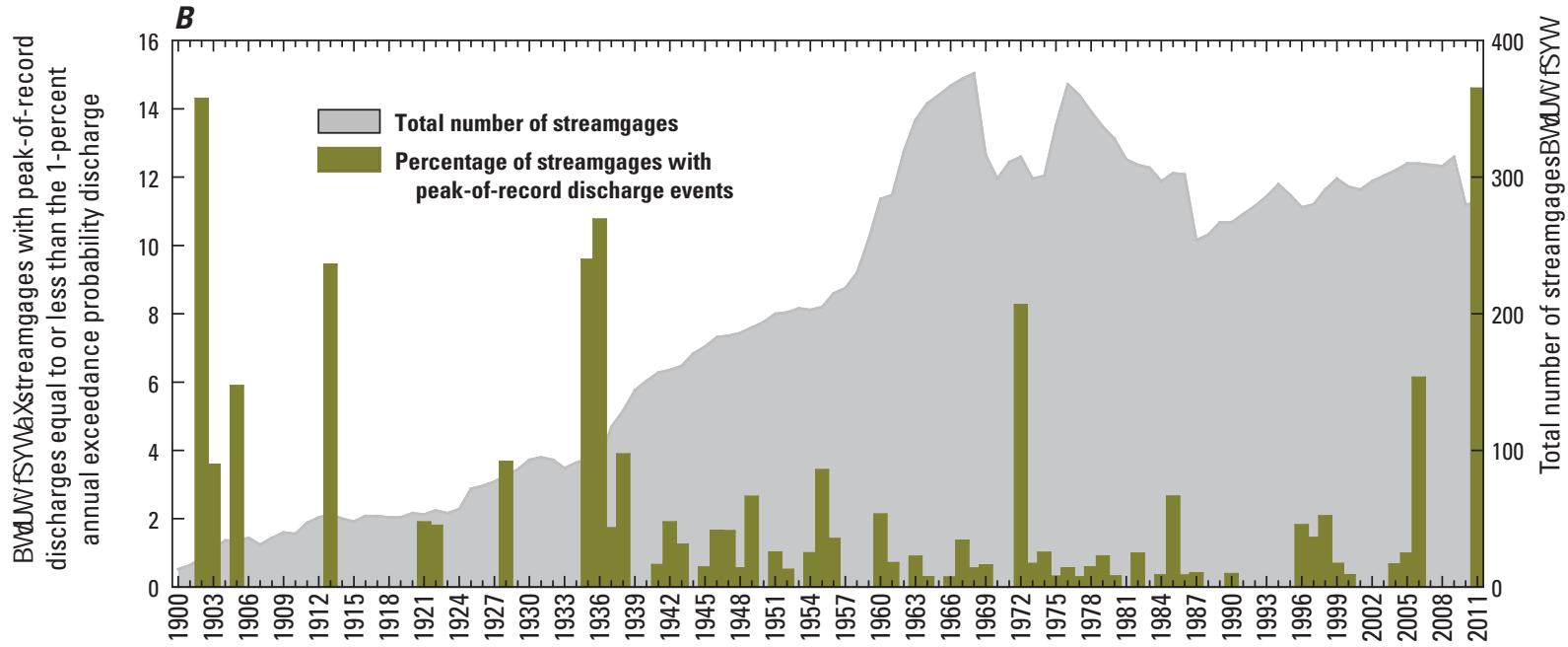

Water year (0ct. 1 to Sept. 30)

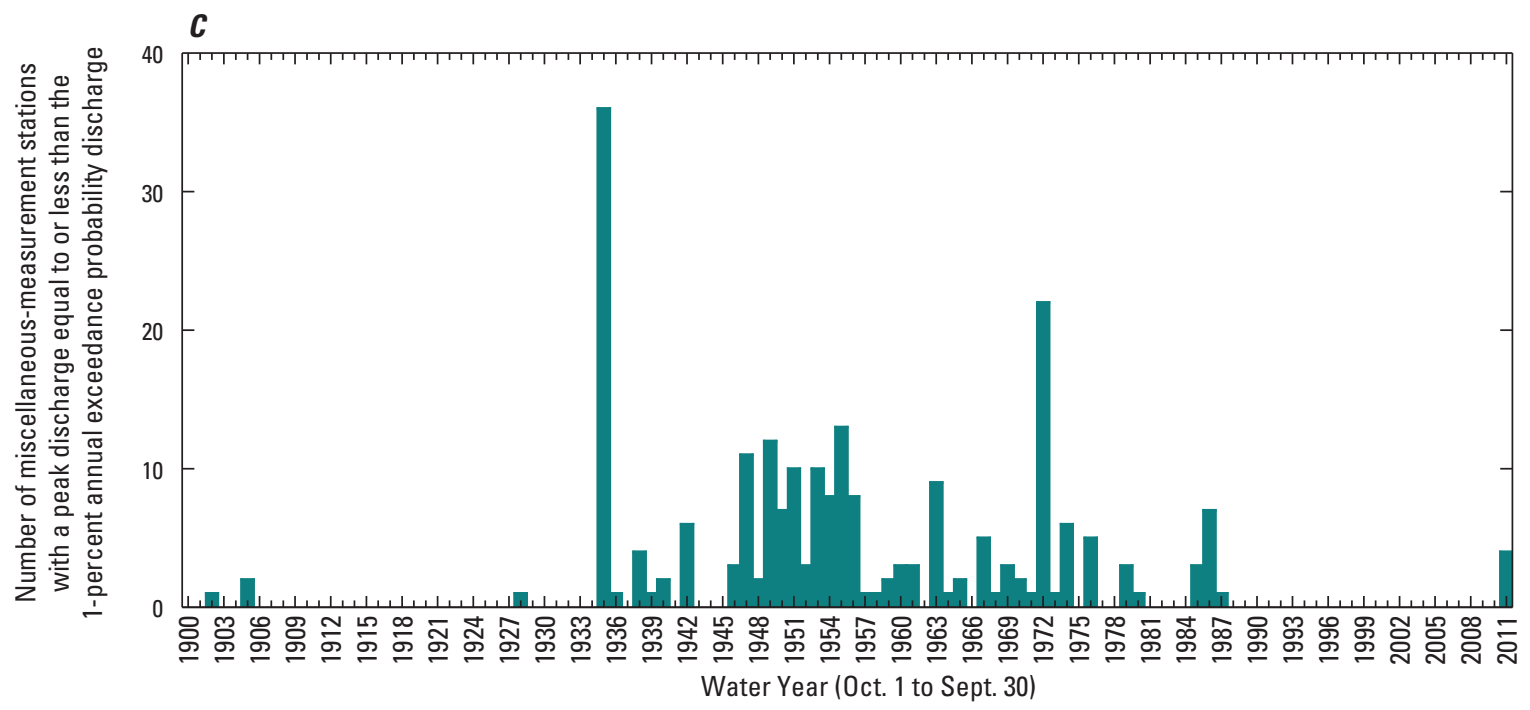

Figure 3. Timing of known peak discharges in the State of New York: $A$, number; $B$, percentage of streamgages with peak-of-record discharge less than or equal to the 1-percent annual exceedance probability (AEP), relative to the number of streamgages in operation; and $C$, peak discharges less than or equal to the 1-percent AEP discharge determined at miscellaneous-measurement sites. 


\section{Spatial Distribution of Maximum Known Discharges and Runoffs}

Maximum known discharge and runoff values (table 1) for the State of New York, each of six hydrologic regions identified by Lumia and others (2006), and Long Island are plotted against drainage area in figures 4 and 5; also plotted are computed 1-percent AEP discharges and associated runoff for unregulated sites with at least 10 years of annual peak-flow data. The wide scatter of observed data (figs. 4-5) could result from differences in (1) periods of record, (2) magnitudes and types of basin characteristics that affect hydrologic response at a specific site, (3) degrees and periods of regulation, (4) detail and extent of documentation of notable floods in an affected area, and (5) measurement errors. The scatter of the 1-percent AEP discharges and runoff values within each hydrologic region can be attributed to local differences in basin characteristics that affect streamflow. Lumia and others (2006) found peak-discharge response affected significantly by 10 basin characteristics including drainage area, channel slope, percentage of basin storage, mean annual precipitation, percentage of basin forest cover, a basin lag factor, mean annual runoff, maximum snow depth, a basin slope ratio, and the percentage of a basin above $1,200 \mathrm{ft}$.

The magnitude of maximum known discharges and associated runoff for the State in relation to drainage area is represented by a New York State "envelope curve" depicted in each of the panels in figures 4 and 5. Maximum discharge and runoff in regions 3-5 predominantly determine the shape of the New York State curve. Envelope curves for each region and Long Island are depicted in figure 6 along with the New York State curve and the maximum envelope curve for the United States from Crippen and Bue (1977). The position of the New York curve in relation to the national curve suggests that the maximum flood-discharge potential (per square mile) of New York streams is less than that of streams in other parts of the United States. Rainfall-intensity maps and a regional analysis of maximum known discharges in the United States by Crippen and Bue (1977) support this conclusion. Discharges (fig. 6A) represented by the national curve range from at least 2.7 to 3.2 times greater than those represented by the New York curve for drainage areas of 1.0 and 1,000 $\mathrm{mi}^{2}$, respectively; similarly, the national runoff (fig. 6B) envelope is at least 2.6 to 3.8 times greater than New York for the same range of drainage areas. Comparative factors between the New York and United States curves are considered minimum values as the United States curves have possibly increased with respect to discharge and runoff events since their publication in 1977.

Boxplots of peak discharge, plotted by region (fig. 7A), indicate that the magnitude of peak discharges is highest in Region 3 (Catskill Mountains area), with the 90th, 75th, 50th, and 25 th percentiles all ranking highest across regions. The ranking of runoff distributions (fig. 7B) is mixed, with Region 4 having the highest 90th percentile value and Region 3 ranking first at the 75th, 50th, 25th, and 10th percentile; Region 5 ranks just behind Region 3 at the 90th, 75th, and 50th percentiles.

Users of this report are invited to submit evidence of peak stages and discharges at sites not listed in this compilation, or data that are known to exceed those listed, to:

U.S. Geological Survey, New York Water Science Center 425 Jordan Road

Troy, New York 12180

\section{Summary}

The U.S. Geological Survey (USGS), in cooperation with the New York State Department of Transportation, compiled maximum known stages and discharges of New York streams from 1865 to 2011. Most of the peak data were obtained from files and previous reports of the USGS, although State, local, and other Federal agencies and private organizations contributed additional peak-data information. Data from 1,400 sites on 796 streams are presented. Data are listed by major drainage basin and by USGS site number (downstream order), site name, latitude and longitude, county, period of record, drainage area, date of flood, gage height, discharge, discharge per square mile, remarks on gage height and discharge, and flood frequency information.

A comparison of maximum known discharges in New York with those from sites throughout the United States suggests a smaller peak-discharge potential in New York than in other areas of potentially high peak discharge within the country. Curves that envelope the upper limit of maximum known discharge and runoff of the six hydrologic regions and Long Island in New York indicate that parts of western New York (Region 5) and the Catskill Mountains (Regions 3 and 4) have the largest documented discharges and discharges per square mile in the State, and Long Island has the smallest. 

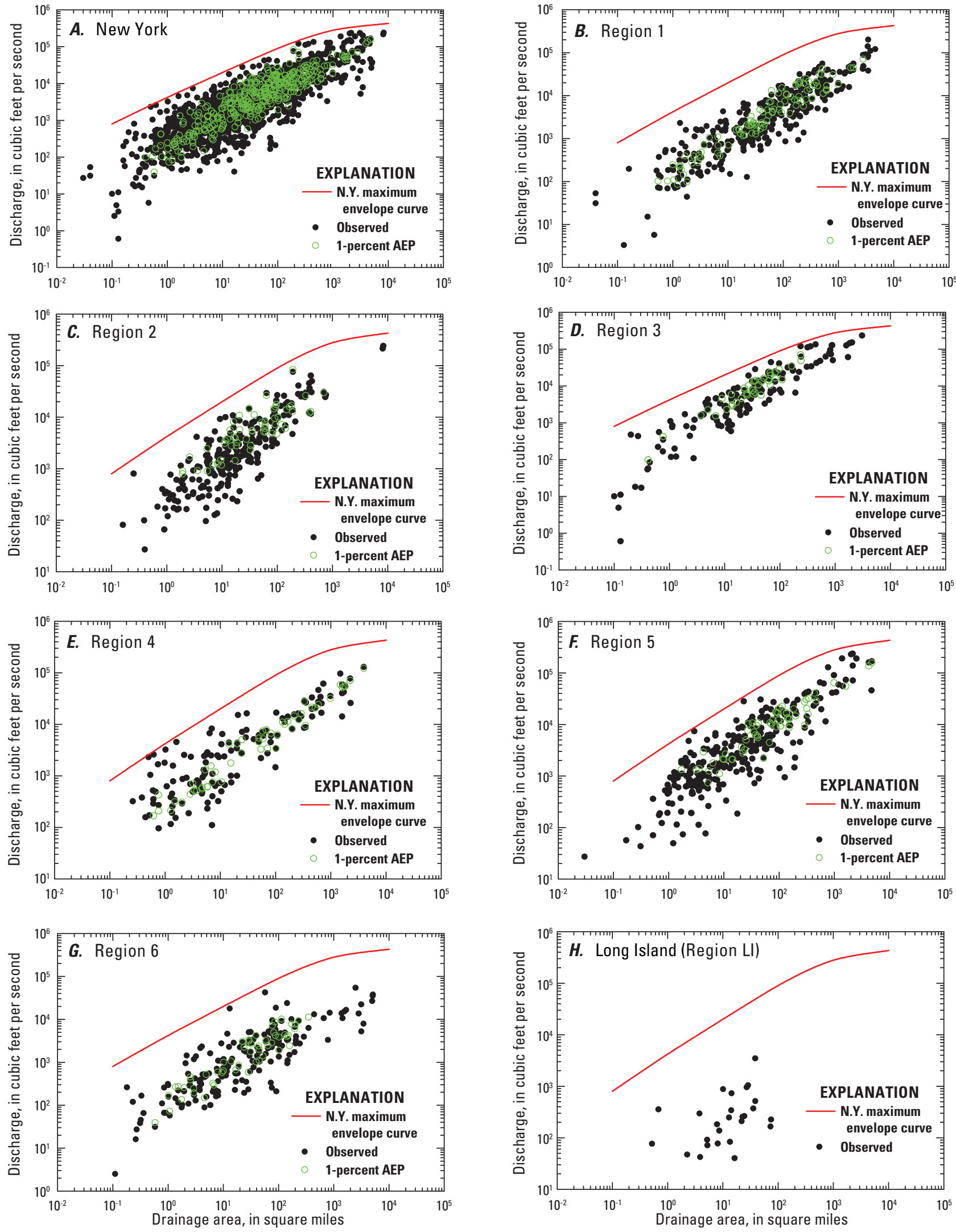

Figure 4. Maximum known discharges, known 1-percent annual exceedance probability (AEP) discharges for Rural10 sites, and the State of New York discharge envelope curve for $A$, State of New York; $B-G$, six hydrologic regions in New York; and $H$, Long Island. 

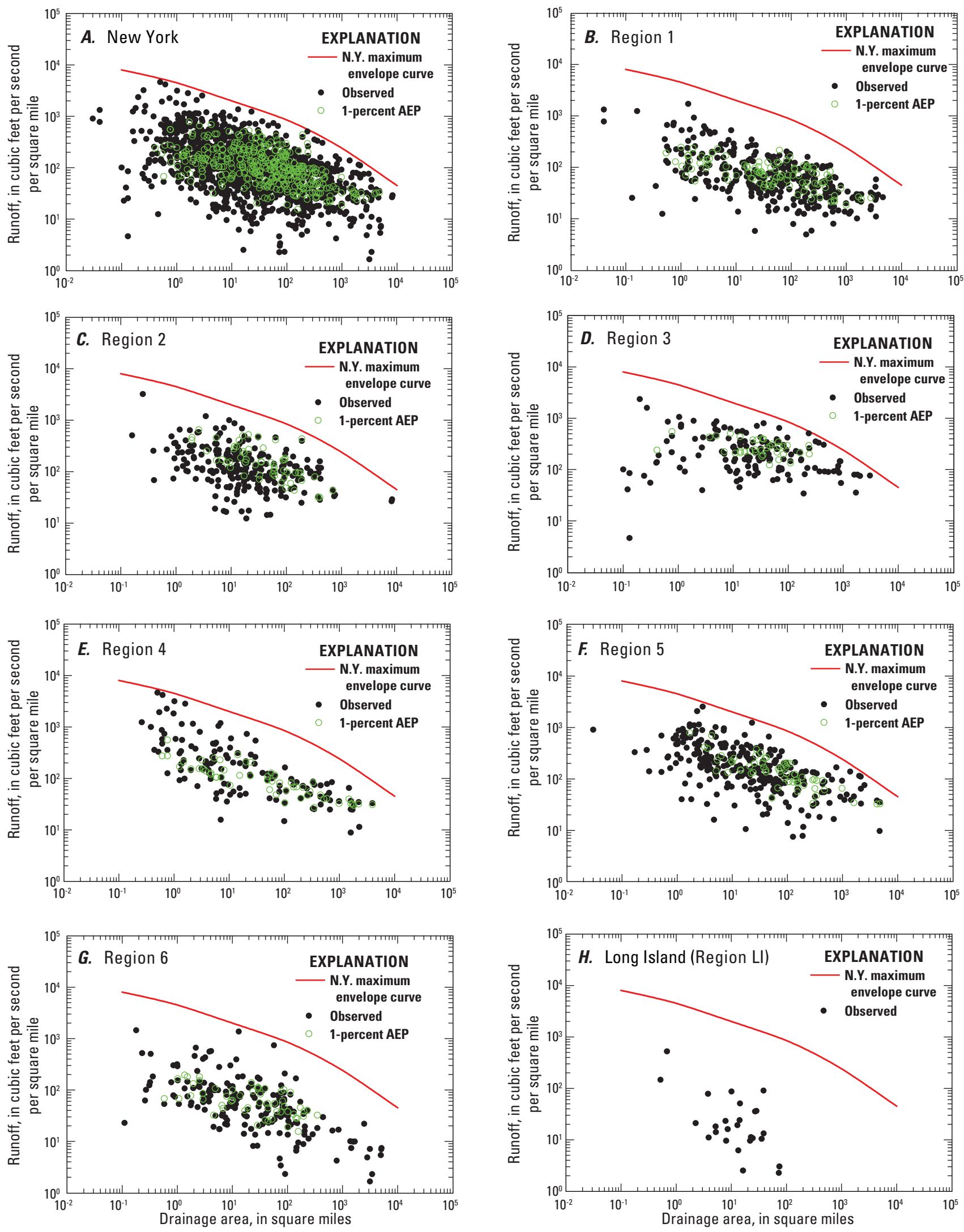

Figure 5. Maximum known runoff, known 1-percent annual exceedance probability (AEP) runoff for Rural10 sites, and the State of New York runoff envelope curve for $A$, State of New York; $B-G$, six hydrologic regions in New York; and $H$, Long Island. 

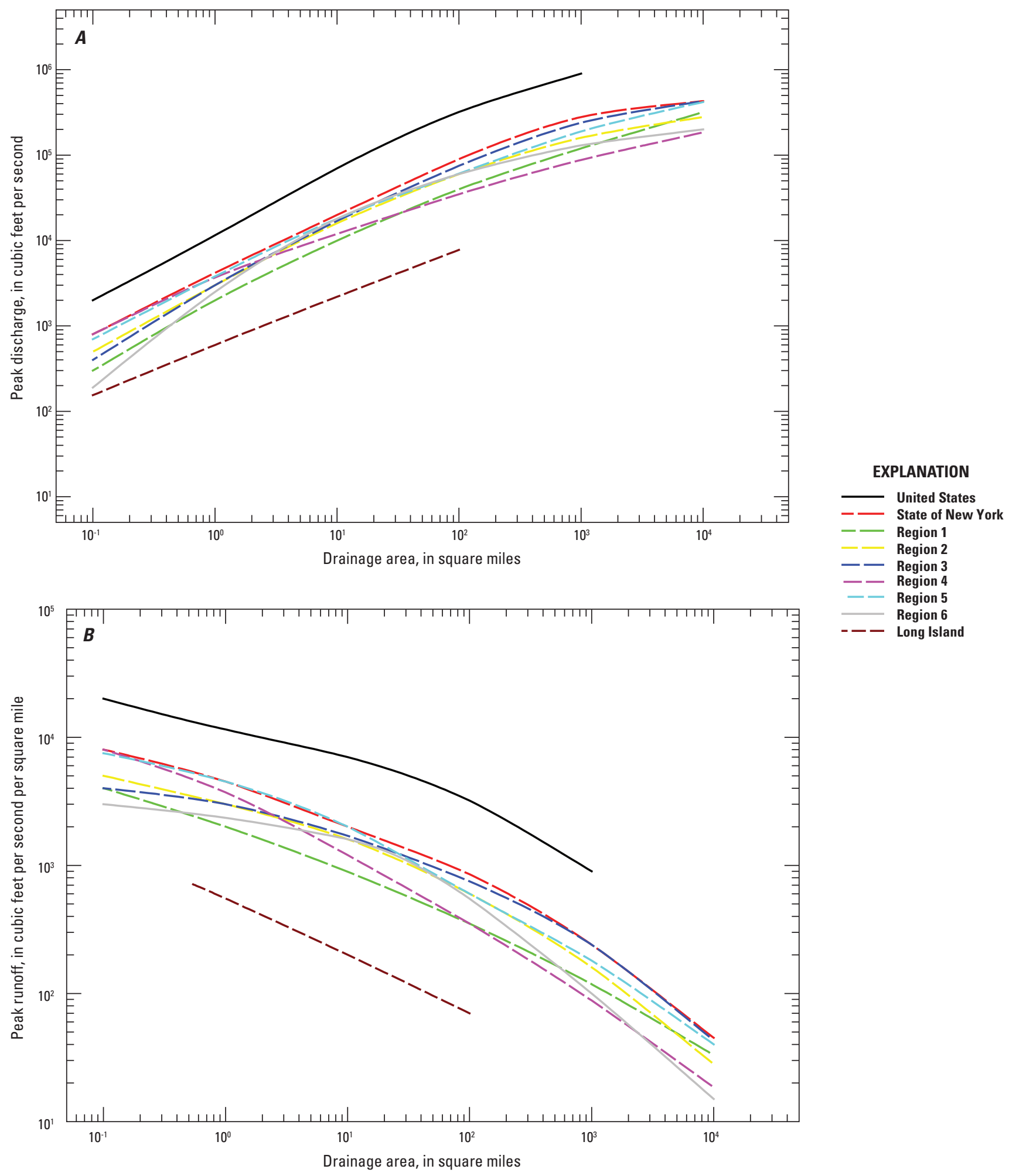

Figure 6. Envelope curves for $A$, discharge and $B$, runoff for the United States (Crippen and Bue, 1977), State of New York, six hydrologic regions in New York, and Long Island. 

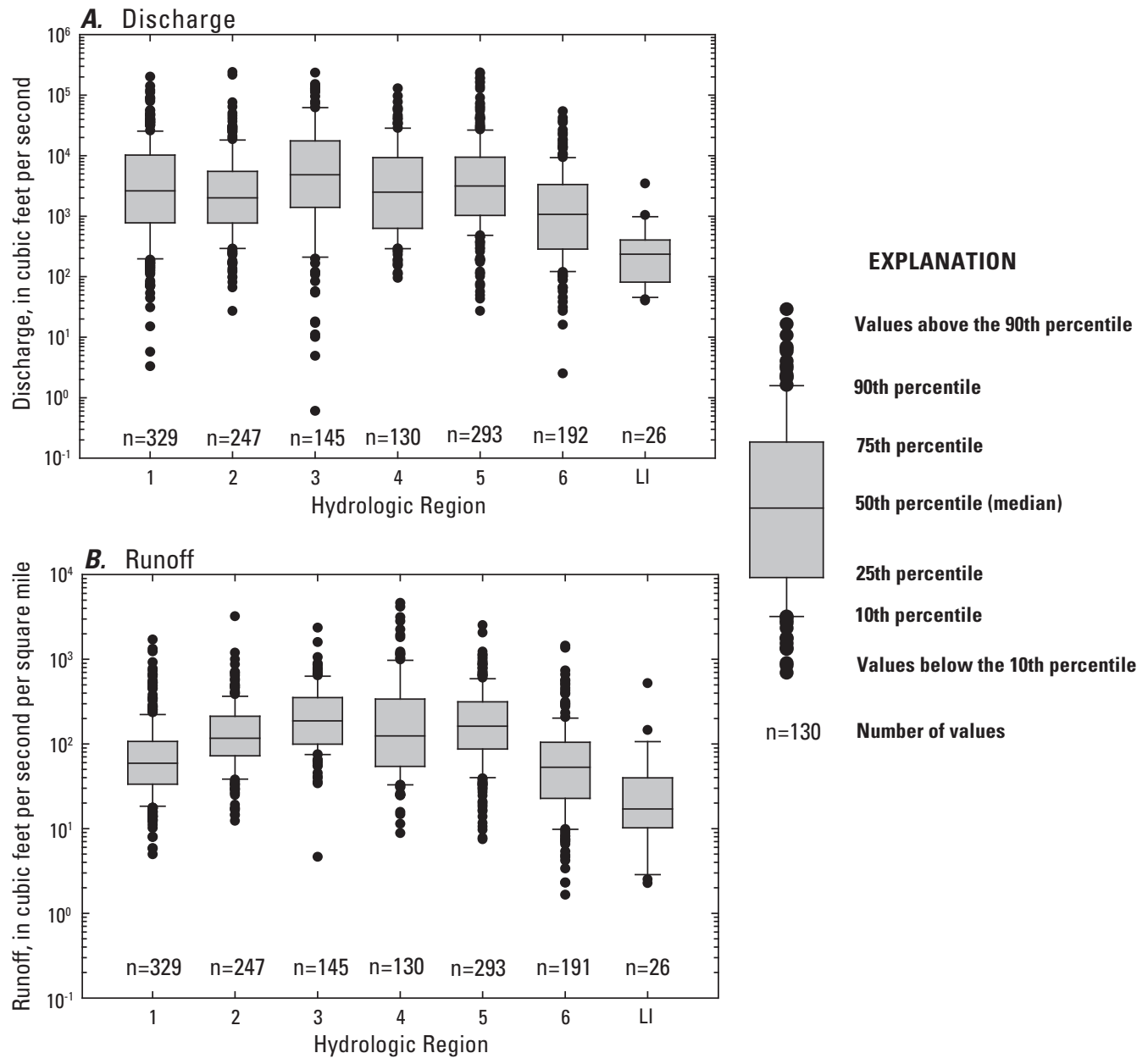

50th percentile (median)

25th percentile

10th percentile

Values below the 10th percentile

$n=130 \quad$ Number of values

Figure 7. Distribution of maximum known $A$, discharge and $B$, runoff from 1,362 locations across six hydrologic regions in New York and Long Island (Region LI). Runoff was not computed at one location in Region 6 (Erie (Barge) Canal at Lock 30, at Macedon, NY), because the location drainage area could not be determined. 


\section{References Cited}

Bodhaine, G.L., 1968, Measurement of peak discharge at culverts by indirect methods: U.S. Geological Survey Techniques of Water-Resources Investigations, book 3, chap. A3, $60 \mathrm{p}$.

Crippen, J.R., and Bue, C.D., 1977, Maximum floodflows in the conterminous United States: U.S. Geological Survey Water-Supply Paper 1887, 52 p.

Dalrymple, Tate, and Benson, M.A., 1967, Measurement of peak discharge by the slope-area method: U.S. Geological Survey Techniques of Water-Resources Investigations, book 3, chap. A2, $12 \mathrm{p}$.

Dunn, Bernard, 1970, Maximum known stages and discharges of New York streams through 1967: New York State Conservation Department, Water Resources Commission Bulletin 67, $57 \mathrm{p}$.

Fischer, E.A., 1937, Report on flood conditions in the Genesee River: Rochester, N.Y., Henderson-Mosher, 251 p.

Gravlee, G.C., Jr., Lumia, Richard, and Wolcott, S.W., 1991, New York floods and droughts, in U.S. Geological Survey, National water summary 1988-89-Hydrologic events and floods and droughts: U.S. Geological Survey Water-Supply Paper 2375, p. 415-424.

Grover, N.C., 1937, The floods of March 1936: Part 2. Hudson River to Susquehanna River Region: U.S. Geological Survey Water-Supply Paper 799, 380 p.

Hendricks, E.L., 1964, Compilation of records of surface water of the United States, October 1950 to September 1960, Part 1-B, North Atlantic slope basins, New York to York River: U.S. Geological Survey Water-Supply Paper $1722,578 \mathrm{p}$.

Hulsing, Harry, 1967, Measurement of peak discharge at dams by indirect methods: U.S. Geological Survey Techniques of Water-Resources Investigations, book 3, chap. A5, 29 p.

Interagency Advisory Committee on Water Data, 1982, Guidelines for determining flood flow frequency - Bulletin 17B of the Hydrology Subcommittee: Reston, Va., U.S. Geological Survey, Office of Water Data Coordination, U.S. $183 \mathrm{p}$.

Johnson, Hollister, 1936, The New York State flood of July 1935: U.S. Geological Survey Water- Supply Paper 773-E, $278 \mathrm{p}$.

Leonard, I.R., and Dunn, Bernard, 1976, Maximum known stages and discharges of New York streams through 1973: New York State Department of Environmental Conservation Bulletin 72, $67 \mathrm{p}$.
Lumia, Richard, and Baevsky, Y.H., 2000, Development of a contour map showing generalized skew coefficients of annual peak discharges of rural, unregulated streams in New York, excluding Long Island, U.S. Geological Survey Water-Resources Investigations Report 00-4022, 11 p.

Lumia, Richard, Freehafer, D.A., and Smith, M.J., 2006, Magnitude and frequency of floods in New York: U.S. Geological Survey Scientific Investigations Report 2006-5112, $152 \mathrm{p}$.

Lumia, Richard, and Murray, P.M., 1993, Maximum known stages and discharges of New York streams, 1865-1989, with descriptions of five selected floods, 1913-85: U.S. Geological Survey Water-Resources Investigations Report 92-4042, $123 \mathrm{p}$.

Matthai, H.F., 1967, Measurement of peak discharge at width contractions by indirect methods: U.S. Geological Survey Techniques of Water-Resources Investigations, book 3, chap. A4, 44 p.

Rafter, G.W., 1905, Hydrology of the State of New York: Albany, N.Y., New York State Museum Bulletin 85, 902 p.

Ries, K.G., III, Crouse, M.Y., comps., 2002, The National Flood Frequency Program, Version 3-A computer program for estimating magnitude and frequency of floods for ungaged sites, 2002: U.S. Geological Survey WaterResources Investigations Report 02-4168, 42 p.

Robideau, J.A., Burke, P.M., and Lumia, Richard, 1984, Maximum known stages and discharges of New York streams through September 1983: U.S. Geological Survey Open-File Report 83-927, 83 p.

Robison, F.L., 1961, Flash flood in the vicinity of Unadilla, NY July 29, 1961, U.S. Geological Survey Flood Memorandum Report No. 41 for New York State Department of Public Works, $15 \mathrm{p}$.

Schopp, R.D., and Firda, G.D., 2008, Flood magnitude and frequency of the Delaware River in New Jersey, New York, and Pennsylvania: U.S. Geological Survey Open-File Report 2008-1203, 9 p.

U.S. Geological Survey, 1952, New Year flood of 1949 in New York and New England: U.S. Geological Survey Circular $155,109 \mathrm{p}$.

U.S. Geological Survey, 1960, Maximum known discharge of New York streams: U.S. Geological Survey Open-File Report, $32 \mathrm{p}$.

U.S. Geological Survey, 1961-75, Water resources data-New York. Part 1, Surface water records: U.S. Geological Survey Water-Data Report (issued annually). 
U.S. Geological Survey, 1971, Index of surface-water records to September 30, 1970; Part 1, North Atlantic slope basins: U.S. Geological Survey Circular 651, 89 p.

U.S. Geological Survey, 1971, Index of surface-water records to September 30, 1970; Part 3, Ohio River Basin: U.S. Geological Survey Circular 653, 71 p.

U.S. Geological Survey, 1971, Index of surface-water records to September 30, 1970; Part 4, St. Lawrence River Basin: U.S. Geological Survey Circular 654, 43 p.

U.S. Geological Survey, 1976, Water resources data, New York, water year 1975: U.S. Geological Survey Water-Data Report NY-75-1, 735 p.
U.S. Geological Survey, 1977-80, Water resources data, New York, water years 1976-79, volume 1, New York excluding Long Island; volume 2, Long Island: U.S. Geological Survey Water-Data Report (issued annually).

U.S. Geological Survey, 1981-2011, Water resources data, New York, water years 1980-2011, volume 1, eastern New York excluding Long Island; volume 2, Long Island; volume 3, western New York: U.S. Geological Survey Water-Data Report (issued annually).

Wells, J. V. B., 1960, Compilation of records of surface waters of the United States through September 1950. Part 1-B, North Atlantic slope basins, New York to York River: U.S. Geological Survey Water-Supply Paper 1302, 679 p. 



\section{Glossary}

Annual Exceedance Probability The probability that flooding of a specified magnitude will be equaled or exceeded in a given year.

Backwater The increased depth of water upstream from a dam or other obstruction in a stream channel resulting from that obstruction.

Continuous-record site A site where data are collected with sufficient frequency to define daily mean values and variations within a day.

\section{Contracted-opening discharge measurement A} determination of peak discharge after a flood by field survey of high-water marks and channel and bridge geometry at a bridge constriction. Discharge is computed from an evaluation of energy changes between the approach section and the downstream side of the constriction (Matthai, 1967).

Control Designates a feature in the channel that physically affects the water-surface elevation and thereby determines the stage-discharge relation at the gage. This feature may be a constriction of the channel, a bedrock outcrop, a gravel bar, an artificial structure, or a uniform cross section over a long reach of the channel.

Datum A surface or point relative to which measurements of height and (or) horizontal position are reported. A vertical datum is a horizontal surface used as the zero point for measurements of gage height, stage, or elevation; a horizontal datum is a reference for positions given in terms of latitude-longitude.

Discharge, or flow The rate that matter passes through a cross section of a stream channel or other water body per unit of time. The term commonly refers to the volume of water (including, unless otherwise stated, any sediment or other constituents suspended or dissolved in the water) that passes a cross section in a stream channel, canal, pipeline, and so forth, within a given period of time (cubic feet per second). Discharge also can apply to the rate at which constituents, such as suspended sediment, bedload, and dissolved or suspended chemicals, pass through a cross section, in which cases the quantity is expressed as the mass of constituent that passes the cross section in a given period of time (tons per day).

Downstream order system Since October 1, 1950, hydrologic-site records in U.S. Geological Survey reports have been listed in order according to downstream direction along the main stream. All sites on a tributary entering upstream from a main-stream site are listed before that site.
Drainage area For a stream at a specific location, the area upstream from the location, measured in a horizontal plane, which has a common outlet at the site for its surface runoff from precipitation that normally drains by gravity into a stream. Drainage areas given herein include all closed basins, or noncontributing areas, within the area unless otherwise specified.

Drainage basin A part of the Earth's surface that contains a drainage system with a common outlet for its surface runoff. (See "Drainage area")

Elevation Generally refers to height in feet above North American Vertical Datum of 1988 (formerly mean sea level).

Flood A relatively high flow as measured by gage height or discharge quantity.

Flood recurrence interval The average time interval between occurrences of a flood of equal or greater magnitude. A 100-year flood has a 1-percent chance of occurring in any 1-year period.

Flow-over-dam discharge measurement A determination of peak discharge after a flood, by field survey of highwater marks and channel and dam geometry. Discharge is computed on the basis of an evaluation of energy changes between the approach section and the control (dam) section (Hulsing, 1967).

Flow-through-culvert discharge measurement A determination of peak discharge after a flood, by field survey of high-water marks and channel and culvert geometry.

Discharge is computed from an evaluation of energy changes between the approach section and the culvert control section (Bodhaine, 1968).

Gage datum A horizontal surface used as a zero point for measurement of stage or gage height. This surface usually is located slightly below the lowest point of the stream bottom such that the gage height is usually slightly greater than the maximum depth of water. Because the gage datum is not an actual physical object, the datum is usually defined by specifying the elevations of permanent reference marks such as bridge abutments and survey monuments, and the gage is set to agree with the reference marks.

Gage height The water-surface elevation, in feet above the gage datum. If the water surface is below the gage datum, the gage height is negative. Gage height often is used interchangeably with the more general term "stage," although gage height is more appropriate when used in reference to a reading on a gage. 


\section{Glossary-Continued}

Pearson type III A statistical distribution used in flood frequency analysis to determine the probability that a given flow will occur within a given time interval.

Miscellaneous-measurement site A site where streamflow, sediment, and (or) water-quality data or water-quality or sediment samples are collected once, or more often on a random or discontinuous basis, to provide better areal coverage for defining hydrologic and water-quality conditions over a broad area in a river basin.

Partial-record site A site where discrete measurements of one or more hydrologic parameters are obtained over a period of time without continuous data being recorded or computed.

A common example is a crest-stage gage partial-record site, at which only peak stages and flows are recorded.

Peak stage The maximum water-surface elevation, above an arbitrary datum of reference, that occurs at a given place over a relatively short period.

Period of record Period of time during which a systematic effort was made at a site to record hydrologic data, including the annual peak stage and discharge.

Runoff That part of precipitation that appears in streams. As used in this report, it is the average number of cubic feet of water flowing per second from each square mile of area drained, assuming that the runoff is distributed uniformly in time and area.

Skew A numerical measure of asymmetry in a frequency distribution.
Slope-area discharge measurement A determination of peak discharge made after a flood, by field survey of a reach of channel and high-water marks at selected cross sections. The U.S. Geological Survey applies the Manning equation to compute peak discharge in open channels (Dalrymple and Benson, 1967).

Stage (See "Gage height")

Step-backwater computation The general procedure for establishing a stage-discharge relation by the step-backwater method includes a transit-stadia survey of a long reach downstream from the gage, an estimate of a stage-discharge relation at the downstream end of the reach, and a computation of water-surface profiles in the reach for selected discharges. The end result of this procedure is a computed water-surface elevation at the streamgage corresponding to each selected discharge.

Streamgage An instrumented site on a stream, where the annual peak discharge is observed (or estimated) for each year observations are obtained.

Water year A continuous 12-month period, arbitrarily selected for the presentation of data relative to hydrologic or meteorologic phenomena. The U.S. Geological Survey water year represents October 1 through September 30 and it is designated by the calendar year in which it ends. For example, October 1, 1980, through September 30, 1981, is the 1981 water year. 
Prepared by the Pembroke and Lafayette Publishing Service Center.

For more information concerning this report, contact:

Director

U.S. Geological Survey

New York Water Science Center

425 Jordan Road

Troy, NY 12180-8349

dc_ny@usgs.gov

or visit our Web site at:

http://ny.water.usgs.gov 
